Int. J. Odontostomat., 6(2):145-150, 2012.

\title{
Chronic Temporomandibular Pain Treatment Using Sodium Diclofenac
}

\author{
Tratamiento crónico del dolor temporomandibular con diclofenaco sódico
}

Fernando Kurita Varoli*; Sandra Sato*; Murillo Sucena Pita*; Cássio do Nascimento* \& Vinícius Pedrazzi ${ }^{* * *}$

VAROLI, F. L.; SATO, S.; PITA, M. S.; NASCIMENTO, C. \& PEDRAZZI, V. Chronic temporomandibular pain treatment using sodium diclofenac. Int. J. Odontostomat., 6(2):145-150, 2012.

ABSTRACT: This study evaluate spontaneous pain after and before administration of sodium diclofenac, isolated or associated to carisoprodol, acetaminophen and caffeine, in chronic temporomandibular disorders (TMD) patients. Were selected eighteen volunteers, both men and women, between 35-70 years of age (mean age 50 years). The inclusion criteria was masticatory muscle pain, and the Research Diagnostic Criteria for Temporomandibular Disorders (RDC/TMD) was used on the diagnose. The selection of treatment for each individual was done by a triple-blind full-randomized crossover methodology. Thus, all patients were submitted to all treatment at different moments, in a non standardized sequence, avoiding tendentious results. The treatments were: A (sodium diclofenac + carisoprodol + acetaminophen + caffeine), B (sodium diclofenac) and C (placebo), all associated with an occlusal splint. Each treatment period was followed by an eleven-day washout. There weren't observed differences between initial and final values of treatments. However, there were statistically significant differences in evaluative and miscellaneous sensorial groups after B treatment; and in sensorial, affective, and total score groups after B and C treatments. Within the limitations of this investigation, we conclude that treatment of muscular TMD patients with sodium diclofenac isolated promoted higher analgesia than treatment with sodium diclofenac more associations or placebo, when associated to an occlusal splint.

KEY WORDS: diclofenac, facial pain, non-steroidal anti-inflammatory agents, temporomandibular joint disorders, temporomandibular joint dysfunction syndrome.

\section{INTRODUCTION}

Temporomandibular disorders (TMD) are a subgroup of musculoskeletal and rheumatologic disturbs that affects the orofacial region (Mohl, 1993; Macfarlane et al., 2001). They are characterized by masticatory muscle pain and temporomandibular joint (TMJ) dysfunction, and usually restricted to head and neck (Capra \& Ro, 2004).

In Dentistry, temporomandibular pain is the second most frequent complain, only less common than dental pain (Harris, 1987). Masticatory muscle pain is probably consequence of traumas or algogenic substances release derived of overloaded activity. Those events could cause microlesions on myofibrils and the release of inflammatory mediators, like bradikinin and prostaglandin E2, that induce and facilitate nociception and lead to an inhibitory reflex activity of muscular activity in the central nervous system (Arendt-Nielsen \& GravenNielsen, 2008; Dina et al., 2008; Costigan et al., 2009).

The early treatment of TMD is desirable, to avoid neuronal circuits alterations, as neuroplasticity and secondary hyperalgesia caused by persistent afferent stimuli (Wang et al., 2009) or psychosocial modulation (Stiles \& Wright, 2008). Thus, nonsteroidal anti-inflammatory (NSAID) could be useful to inhibit inflammatory mediators release on painful tissues, reducing symptoms, including pain.

* PhD, Department of Dental Materials and Prosthodontics, Faculty of Dentistry of Ribeirão Preto, University of São Paulo, Ribeirão Preto, São Paulo, Brazil.

** MSc, Department of Dental Materials and Prosthodontics, Faculty of Dentistry of Ribeirão Preto, University of São Paulo, Ribeirão Preto, São Paulo, Brazil.

*** Associate Professor, Department of Dental Materials and Prosthodontics, Faculty of Dentistry of Ribeirão Preto, University of São Paulo, Ribeirão Preto, São Paulo, Brazil. 
Thus, the aim of this study was to evaluate spontaneous pain after and before administration of sodium diclofenac, isolated or associated to carisoprodol, acetaminophen and caffeine, in chronic TMD patients.

\section{MATERIAL AND METHOD}

Subject Selection. Eighteen volunteers, both men and women, between 35-70 years of age (mean age 50 years), who were included in a maintenance-care program at the Faculty of Dentistry of Ribeirão Preto University of São Paulo, were enrolled in this study. The inclusion criteria were masticatory muscle pain.

Patient selection was done by anamnesis, with questions about general health. There were excluded individuals: 1) under 18 years old; 2) who were using removable dental prosthesis; 3 ) who were taking other medicament; 4) whose health condition didn't allow intake of NSAID and analgesic drugs; 5) pregnant women; 6) alcoholic addict.

All volunteers received clarification and were invited to subscribe an approval term with general information about the study. The project has been submitted and approved by Ethics Research Committee involving Human Beings of Faculty of Dentistry of Ribeirão Preto of USP (Lawsuit n.2006.1.558.58.0, Caae n. 0022.0.138.000-06).

Experimental Design (Treatment Protocol). The execution of clinical and laboratorial steps was performed by the same researcher to avoid interexaminer differences, standardizing all procedures and decreasing any result interference. The Research Diagnostic Criteria for Temporomandibular Disorders (RDC/TMD) was used on the diagnose.

After, were made a flat, full-covered and rigid occlusal splint for each volunteer. They had canine guide with equipotent and simultaneous contact points in centric relation.

Patients' pain were measured by Brazilian Portuguese McGill Pain Questionnaire (MPQ) (Varoli \& Pedrazzi, 2006), filled by themselves after researcher orientation. Pain assessment were done after and before each treatment proposed in this study.

The treatments were: A (sodium diclofenac + carisoprodol + acetaminophen + caffeine), B (sodium diclofenac) and $C$ (placebo), all associated with an occlusal splint. The selection of treatment for each individual was done by a triple-blind full-randomized crossover methodology. Thus, all patients were submitted to all treatment at different moments, in a non standardized sequence, avoiding tendentious results. Each treatment period was followed by an eleven-day washout.

Drugs used in this study were shown in Table I, with information about composition, active ingredients, concentration, manufacturer and lot.

Medicament $A$ and $B$ were bought by PostGraduation Committee (Oral Rehabilitation), by quotation in a pharmacy. The medicament $C$ was manufactured by Faculty of Pharmaceutical Sciences of Ribeirão Preto - USP, in capsule shape.

During treatment, individuals were oriented to take two daily medicament dosages, following manufacturer recommendation, during ten days, followed by an eleven-day washout, and started after the last dosage of each drug. All patients were instructed to not using the occlusal splint neither take any medicament during washout period.

Data Analysis . All spontaneous pain data collected were submitted to an initial exploratory analysis of all six MPQ groups (sensorial, affective, evaluative, miscellaneous sensorial, miscellaneous affectiveevaluative and total).

For statistical analysis, there were used nonparametric statistic methods, because data normality weren't observed. The Friedman's test was used to compare initial and final values of each treatment and the Wilcoxon's test, to compare 3 times initial and final data (after and before each treatment). Differences were considered significant when $p<0.05$.

\section{RESULTS}

There weren't observed differences between initial and final values of treatments. However, there were statistically significant differences in evaluative (Fig. 1) and miscellaneous sensorial (Fig. 2) groups after B treatment; and in sensorial (Fig. 3), affective (Fig. 4), and total score (Fig. 5) groups after B and C treatments. 
VAROLI, F. L.; SATO, S.; PITA, M. S.; NASCIMENTO, C. \& PEDRAZZI, V. Chronic temporomandibular pain treatment using sodium diclofenac.

Int. J. Odontostomat., 6(2):145-150, 2012.

Table I. Medicaments, active ingredients, composition, manufacturer and lot.

\begin{tabular}{|c|c|c|c|c|}
\hline Medicament & $\begin{array}{c}\text { Active } \\
\text { Ingredients }\end{array}$ & $\begin{array}{c}\text { Concentratio } \\
\mathrm{n}\end{array}$ & Manufacturer & Lot $n^{\circ}$ \\
\hline $\begin{array}{c}A \\
\text { Register } n^{\circ} \\
1.0370 .0150 .003-6\end{array}$ & $\begin{array}{l}\text { Acetaminophen } \\
\text { Sodium Diclofenac } \\
\text { Carisoprodol } \\
\text { Caffeine }\end{array}$ & $\begin{array}{l}300 \mathrm{mg} \\
50 \mathrm{mg} \\
125 \mathrm{mg} \\
30 \mathrm{mg}\end{array}$ & $\begin{array}{c}\text { Teuto Laboratory } \\
\text { (Anápolis-GO, Brasil) }\end{array}$ & 0183567 \\
\hline $\begin{array}{c}B \\
\text { Register } n^{\circ} \\
1.0370 .0070 .003-7\end{array}$ & $\begin{array}{l}\text { Sodium } \\
\text { Diclofenac }\end{array}$ & $50 \mathrm{mg}$ & $\begin{array}{c}\text { Teuto Laboratory } \\
\text { (Anápolis-GO, Brasil) }\end{array}$ & 0040284 \\
\hline $\begin{array}{c}\text { C } \\
\text { Placebo (control) }\end{array}$ & Cornstrch & $110 \mathrm{mg}$ & $\begin{array}{c}\text { Faculty of } \\
\text { Pharmaceutical } \\
\text { Sciences of Ribeirão } \\
\text { Preto - USP }\end{array}$ & \\
\hline
\end{tabular}

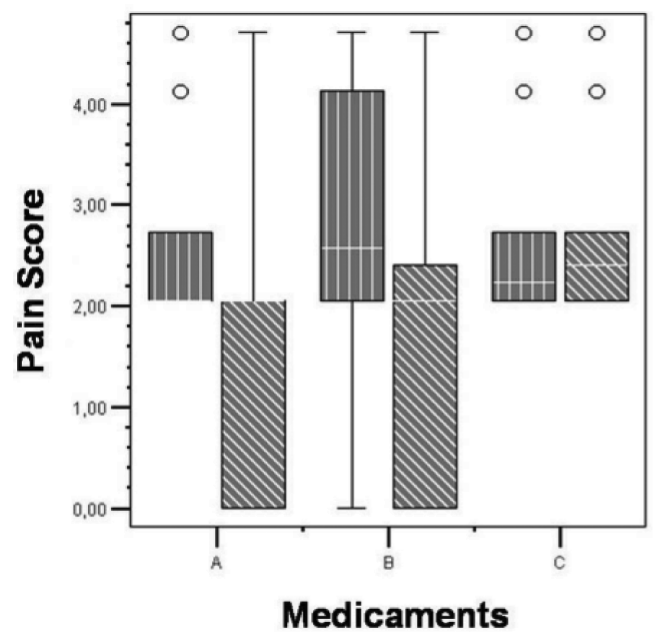

Fig. 1. Evaluative group (MPQ).

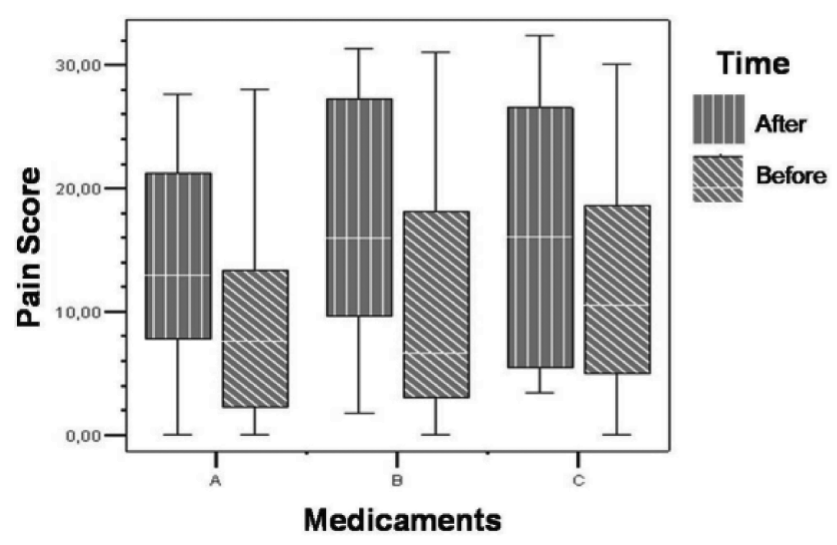

Fig. 3. Sensorial group (MPQ).

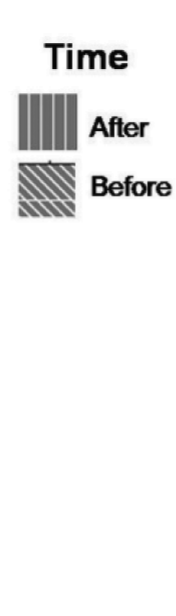

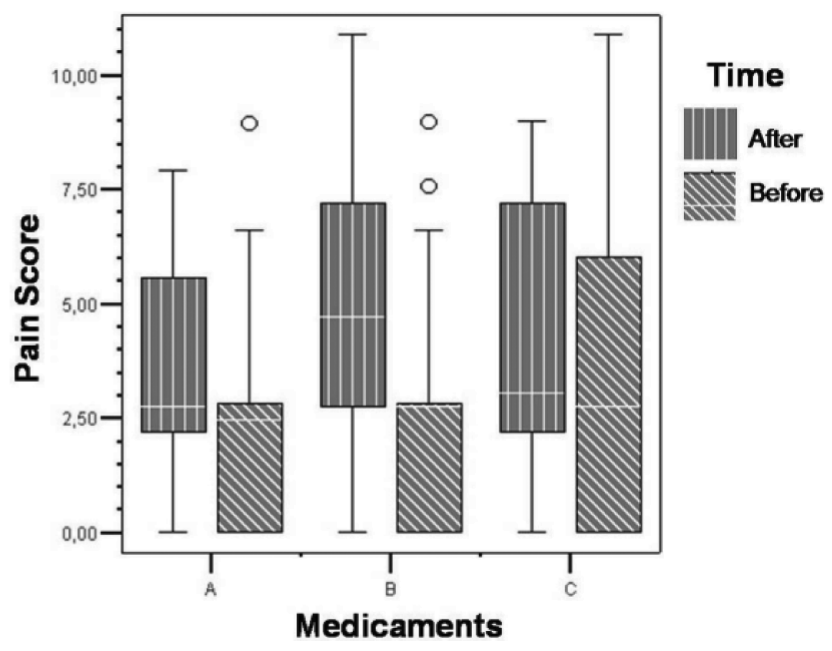

Fig. 2. Miscellaneous sensorial group (MPQ).

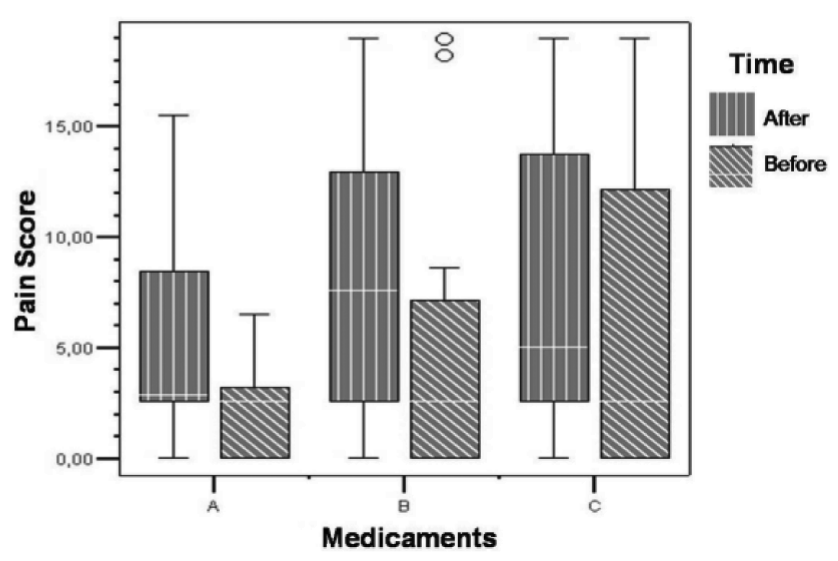

Fig. 4. Affective group (MPQ). 


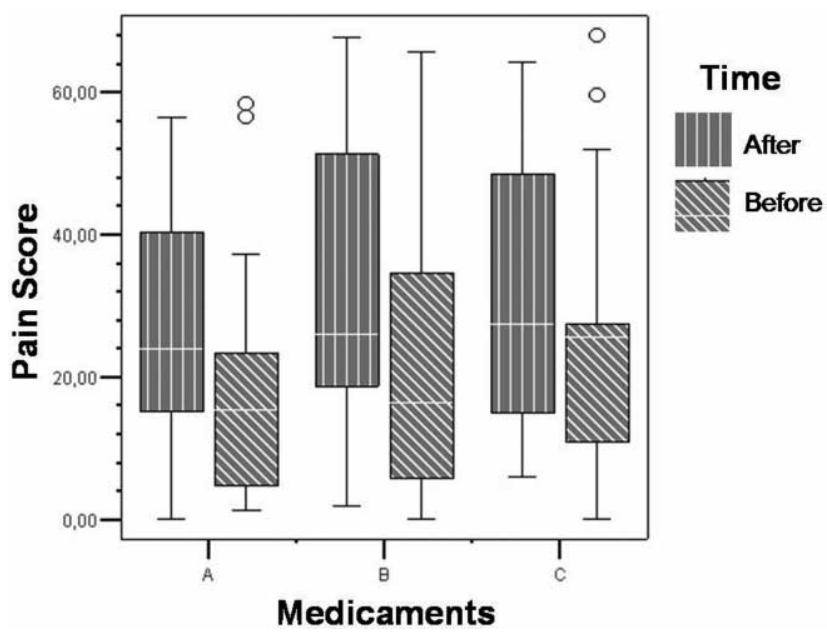

Fig. 5. Total score (MPQ).

\section{DISCUSSION}

The diagnose method using RDC/TMD, well defined inclusion/exclusion criteria, and crossover full randomized clinical methodology were essential to reduce any possible vicious of this clinical study (James et al., 1985). Control group was important to verify medicament A and B efficacy, and occlusal splint were fundamental to make this study ethically practicable because, even during control treatment, patients were receiving a widely accepted and known TMD therapy (Ekberg \& Nilner, 2004; Ferrario et al., 2002; Forssell et al., 1999; Wassell et al., 2006).

In a systematic review, Forssell et al. (1999) found evidence about the benefits of treatment with occlusal splints in remission of the symptoms of TMD patients.

Ferrario et al., in a study using electromyography, found that immediately after the installation of occlusal splints, there was a significant reduction in activity of the masseter and temporal muscles, promoting a reduction of the overload on the TMJs, a more balanced bilateral muscle activity as well as a better balance between the activity of these two muscles on the same side. After using the interocclusal device for 5 weeks, observed a reduction or remission of painful symptoms.

Wassell et al. (2006) found that after the use of occlusal splints for a period of one year, patients reported an improvement in symptoms, including the incidence of TMJ clicks. Thus, the appliance continues to promote benefic effects on the symptoms with their use for a longer time.
In a study by Ekberg \& Nilner, the authors observed that the symptoms of TMD were reduced after the use of occlusal splints and remained asymptomatic for a period of 6 to 12 months after the treatment with interocclusal device.

The inicial hypothesis of this study was that a NSAID (Sodium Diclofenac) could inhibit inflammatory mediators release after microtraumas on the myofibrils of masticatory muscles (Arendt-Nielsen \& GravenNielsen) and in TMJ (Swift et al., 1998). When associated to a muscle relaxant (carisoprodol), an analgesic (acetaminophen) and a adjuvant central analgesic (caffeine), pain reduction could be improved.

Spontaneous pain reduction, assessed by Brazilian Portuguese MPQ, occurred after treatment $B$ and $C$, but only the first was statistically efficient in subgroups evaluative and miscellaneous sensorial. Sensorial, affective and total score reduction weren't statistically different of that obtained with control treatment.

Results showed more efficient pain reduction by medicament $B$ than medicament $A$ on subgroups sensorial, affective, evaluative, miscellaneous sensorial and total score.Placebo was better than medicament A on subgroups sensorial, affective and total score.

Pain at rest is related to inflammatory mediators acting locally, causing spontaneous pain and peripheral sensitization. In such case, patient feels pain even in absence of nociceptive stimuli (Costingan et al.). Besides, central sensitization can occur, that is, second order neuronal hyperexcitability can cause hyperalgesia, alodinia and spontaneous pain, and is frequent in chronic pain patients (Babenko et al., 1999; Merrill, 2007). At the same time, inhibitory descendent system activity could be reduced and psychosocial pain modulation could exacerbate pain sensation (Okeson \& De Leeuw, 2011).

The aim of pharmacotherapy associated to occlusal splint therapy is to reduce altered muscle tonus, masticatory muscle and TMJ microtrauma and inflammatory mediators release that active or facilitate generation of nociceptive impulses in peripheral receptors (Swift et al.; Bodéré et al., 2005; Merrill; Arendt-Nielsen \& Graven-Nielsen; Dina et al.; Costingan et al.). Therefore, peripheral sensitization and noxious stimuli reduction on muscular and joint tissues could be responsible for partial pain reduction in these patients. Other desirable effect was in 
psychological/emotional aspect, considering that an individual receiving a splint and drug therapy fell assisted, improving his form to confront his problem (Turner et al., 1994; Koshi \& Short, 2007).

It is clear by score reduction on MPQ affective group after B and C treatment. According to Yap (1998), about $39 \%$ of patients who suffer from musculoskeletal orofacial pain are psychological depressed and $55 \%$ has symptoms that, apparently doesn't have physical cause.

But the most interesting fact was absence of analgesia improvement in all MPQ subgroups after treatment $\mathrm{A}$, obtaining worse results than control treatment.

Medicament $B$ is composed by $50 \mathrm{mg}$ of sodium diclofenac, and medicament $A$ has, associated to sodium diclofenac $50 \mathrm{mg}, 125 \mathrm{mg}$ of carisoprodol, $300 \mathrm{mg}$ of paracetamol and $30 \mathrm{mg}$ of caffeine. Besides, they are produced by the same laboratory. Therefore, at least a similar effect was expected.

Sometimes different results in different organisms are obtained with the same drug dosage. Human being must be considered as unique and very complex and it is fundamental when results are unexpected (La Rocca, 1992), even when all precaution to avoid vicious are done.
A possible explanation would be that association of several substances in one medicament, or its shape ( $A$ is a simple tablet and $B$, a covered tablet), could influence absorption and availability.

Other hypothesis for reduced analgesia effect could be medicament appearance. Turner et al. related that placebo can induce different effects, depending on its size and colour. According to authors, bigger tables are associated to higher effect and white colour, to analgesic or narcotic. But, in Brazil, a very common expression "flour tablet" is used for placebo. Therefore, the medicament $A$, that was white and uncoated, could be associated to a tablet without active ingredient, differently of medicament $B$, that was orange and coated, or even placebo, that was a red and white capsule.

\section{CONCLUSION}

Within the limitations of this investigation, we conclude that treatment of muscular TMD patients with sodium diclofenac isolated promoted higher analgesia than treatment with sodium diclofenac more associations or placebo, when associated to an occlusal splint.

VAROLI, F. L.; SATO, S.; PITA, M. S.; NASCIMENTO, C. \& PEDRAZZI, V. Tratamiento crónico del dolor temporomandibular con diclofenaco sódico. Int. J. Odontostomat., 6(2):145-150, 2012.

RESUMEN: Este estudio evaluó el dolor espontáneo antes y después de la administración de diclofenaco sódico, aislado o asociado a carisoprodol, paracetamol y cafeína, en pacientes con trastornos temporomandibulares crónicos (TTM). Se seleccionaron dieciocho voluntarios, hombres y mujeres, entre 35-70 años de edad (edad media 50 años). Los criterios de inclusión fueron dolor muscular masticatorio, y los criterios diagnósticos para trastornos temporomandibulares (RDC /TMD) como diagnóstico. La selección del tratamiento para cada individuo se llevó a cabo mediante una metodología de cruce triple ciego completo al azar. Por lo tanto, todos los pacientes fueron sometidos a todos los tratamientos en diferentes momentos, en una secuencia no estandarizada, evitando los resultados tendenciosos. Los tratamientos fueron: A (diclofenaco sódico + carisoprodol + acetaminofen + cafeína), B (diclofenaco sódico) y C (placebo), todos asociados a una férula oclusal. Cada período de tratamiento fue seguido por once días. No se encontraron diferencias entre los valores inicial y final de los tratamientos. Sin embargo, hubo diferencias estadísticamente significativas en los grupos de evaluación sensorial y después del tratamiento B, y en los grupos de calificación sensorial, afectivo, y el total después de los tratamientos $\mathrm{B}$ y $\mathrm{C}$. Dentro de las limitaciones de esta investigación, se concluye que el tratamiento con diclofenaco sódico aislado en pacientes con TTM musculares promueve una mayor analgesia que el tratamiento con diclofenaco sódico más asociaciones o placebo, cuando se asocia a una férula oclusal.

PALABRAS CLAVE: diclofenaco, dolor facial, anti-inflamatorio no esteroidal, trastornos de la articulación temporomandibular, síndrome de disfunción de la articulación temporomandibular.

\section{REFERENCES}

Arendt-Nielsen, L. \& Graven-Nielsen, T. Muscle pain: sensory implications and interaction with motor control. Clin. J. Pain, 24(4):291-8, 2008.
Babenko, V.; Graven-Nielsen, T.; Svensson, P.; Drewes, A. M.; Jensen, T. S.; Arendt-Nielsen, L. Experimental human muscle pain induced by intramuscular injections 
of bradykinin, serotonin, and substance P. Eur. J. Pain, 3(2):93-102, 1999.

Bodéré, C.; Téa, S. H.; Giroux-Metges, M. A. \& Woda, A. Activity of masticatory muscles in subjects with different orofacial pain conditions. Pain, 116(1-2):33-41, 2005.

Capra, N. F. \& Ro, J. Y. Human and animal experimental models of acute and chronic muscle pain: intramuscular algesic injection. Pain, 110(1-2):3-7, 2004.

Costigan, M.; Scholz, J. \& Woolf, C. J. Neuropathic pain: a maladaptative response of the nervous system to damage. Annu. Ver. Neurosci., 32(1):1-32, 2009.

Dina, A. O.; Green, P. G. \& Levine, J. D. Role of IL-6 in chronic muscle hyperalgesic priming. Neuroscience, 152(2):521-5, 2008.

Ekberg, E. \& Nilner, M. Treatment outcome of appliance therapy in temporomandibular disorder patients with myofascial pain after 6 and 12 months. Acta Odontol. Scand., 62(6):343-9, 2004.

Ferrario, V. F.; Sforza, C.; Tartaglia, G. M. \& Dellavia, C. Immediate effect of stabilization splint on masticatory muscle activity in temporomandibular disorder patients. J. Oral. Rehabil., 29(9):810-5, 2002.

Forssell, H.; Kalso, E.; Koskela, P.; Vehmanen, R.; Puukka, P. \& Alanen, P. Occlusal treatments in temporomandibular disorders: A qualitative systematic review of randomized controlled trials. Pain, 83(3):54960, 1999.

Harris, M. Medical versus surgical management of temporomandibular joint pain and dysfunction. Br. J. Oral. Maxillofac. Surg., 25(2):113-20, 1987.

James, K. E.; Forrest, W. H. Jr. \& Rose, R. L. Crossover and non-crossover designs in four point parallel line analgesic assays. Clin. Pharmacol. Ther., 37(3):24252, 1985.

Koshi, E. B. \& Short, C. A. Placebo theory and its implication for research and clinical practice: a review of the recent literature. Pain Pract., 7(1):4-20, 2007.

LaRocca, H. A taxonomy of chronic pain syndromes. Spine, 17(10 Suppl):S344-55, 1992.

Macfarlane, T. V.; Glenny, A. M. \& Worthington, H. V. Systematic review of population-based epidemiological studies of oro-facial pain. J. Dent., 29(7):451-67, 2001.
Merrill, R. L. Central mechanisms of orofacial pain. Dent. Clin. North. Am., 51(1):45-59, 2007.

Mohl, N. D. Reliability and validity of diagnostic modalities for temporomandibular disorders. Adv. Dent. Res., 7(2):113-9, 1993.

Okeson, J. P. \& De Leeuw, R. Differential diagnosis of temporomandibular disorders and other orofacial pain disorders. Dent. Clin. North. Am., 55(1):105-20, 2011.

Stiles, T. C. \& Wright, D. Cognitive-behavioural treatment of chronic pain conditions. Nord. J. Psychiatry, 62(4Supp/ 47):30-6, 2008.

Swift, J. Q.; Roszkowski, M. T.; Alton, T. \& Hargreaves, K. M. Effect of intra-articular versus systemic antiinflammatory drugs in a rabbit model of temporomandibular joint inflammation. J. Oral. Maxillofac. Surg., 56(11):1288-95, 1998.

Turner, J. A.; Deyo, R. A.; Loeser, J. D.; Von Korff, M. \& Fordyce, W. E. The importance of placebo effects in pain treatment and research. J. Am. Med. Assoc., 271(20):1609-14, 1994.

Varoli, F. K. \& Pedrazzi, V. Adapted version of the McGill Pain Questionnaire to Brazilian Portuguese. Braz. Dent. J., 17(4):328-35, 2006.

Wang, M. Q.; Xue, F.; He, J. J.; Chen, J. H.; Chen, C. S. \& Raustia, A. J. Missing posterior teeth and risk of temporomandibular disorders. Dent. Res., 88(10):9425, 2009.

Wassell, R. W.; Adams, N. \& Kelly, P. J. The treatment of temporomandibular disorders with stabilizing splints in general dental practice: one-year follow-up. J. Am. Dent. Assoc., 137(8):1089-98, 2006.

Yap, A. U. J. Effects of stabilization appliances on nocturnal parafunctional activities in patients with and without signs of temporomandibular disorders. J. Oral. Rehabil., 25(1):64-8, 1998.

Correspondence to:

Prof. Dr. Vinícius Pedrazzi

University of São Paulo

Faculty of Dentistry of Ribeirão Preto

Department of Dental Materials and Prosthodontics

Av. Café S/N, Ribeirão Preto, SP

CEP: $14040-904$

BRAZIL

Email: Pedrazzi@forp.usp.br

Received: 17-05-2012 Accepted: 12-07-2012 